\title{
AGRICULTURE AND NATURE CONSERVATION IN THE MORAVIAN KARST (CZECH REPUBLIC)
}

\author{
Ivan Balák, Jozef Janèo, Leos Stefka and Pavel Bosák
}

\begin{abstract}
Moravian Karst is a narrow strip of limestone with long history of settlement, agricultural use and man impact to karst. It is naturally divided into smaller units - karst plateaus - separated by deep valleys (glens). Each plateau has different proportion of land use, i.e. the percentage of agricultural land, forests, etc. The agricultural land constitutes now up to $70 \%$ in the north and $\max .30 \%$ in the centre and south of the total area of plateaus. Intensive agricultural use of the arable land since 60ties of this Century caused great impact to quality of soils and groundwater by overdoses of fertilisers and other artificial chemical substances. Detailed research in 1980 to 1997 resulted in a plan of care based on the zonation of land. There were defined zones with different degree of restriction of land use, agricultural activities and application of fertilisers and biocides. Arable lands has been gradually changed to meadows and pastures by introduction of grass since 1987 in the most strictly protected zone to protect especially subsurface karst forms.
\end{abstract}

KEY WORDS: Moravian karst, land use, pollution, nature conservation

\section{Introduction}

Moravian Karst represents the largest and most important karst region of the Czech Republic. Typical forms of endokarst and exokarst are developed here. There is an evidence of life of man in this region even before 100.000 years. The region is characteristic by important cultural and technical monuments.

Moravian Karst represents the region with the longest history of the research of karst sites in the Czech Republic and it played important role in the development of many scientific disciplines. Simultaneously, there are numerous inhabited places with intensive economic activities. The tourism is one of the most developed activities.

The first attempts to protect this unique area are dated back to the time just after the constitution of the independent Czechoslovak republic in 1918. The first natural reserves were established in 1930 and 1933. The Landscape Protected Area of the Moravian Karst was set up on July 7, 1956 by the Decree of Ministry of Education and Culture. The aim of the protected area is to preserve all unique forms of living and lifeless nature, and cultural and technical monuments during the development of considerate forms of the economic utilisation of the region. Nevertheless, the stated intentions have not been completely fulfilled. The document stated the first conditions for the protection of karst phenomena: "Karst forms, subsurface and surficial, especially rocky forms and abris, dolines, sinks, resurgences, caves, shafts, etc. are 
not allowed to be damaged, dolines cannot be filled up". The principles of the utilisation of the agricultural land are stated here, too: "The farming on the cultural land will be carried out according to the present methods. Meadows and pastures will not be changed to fields or other cultures except of the forest, wet places will not be drained".

\section{Geological background}

Moravian Karst represents the strip about $25 \mathrm{~km}$ long and 3 to $6 \mathrm{~km}$ wide developed on Devonian limestones (Fig. 1) north of the city of Brno.

Crystalline basement of Paleozoic formations is built of the intrusive body of the

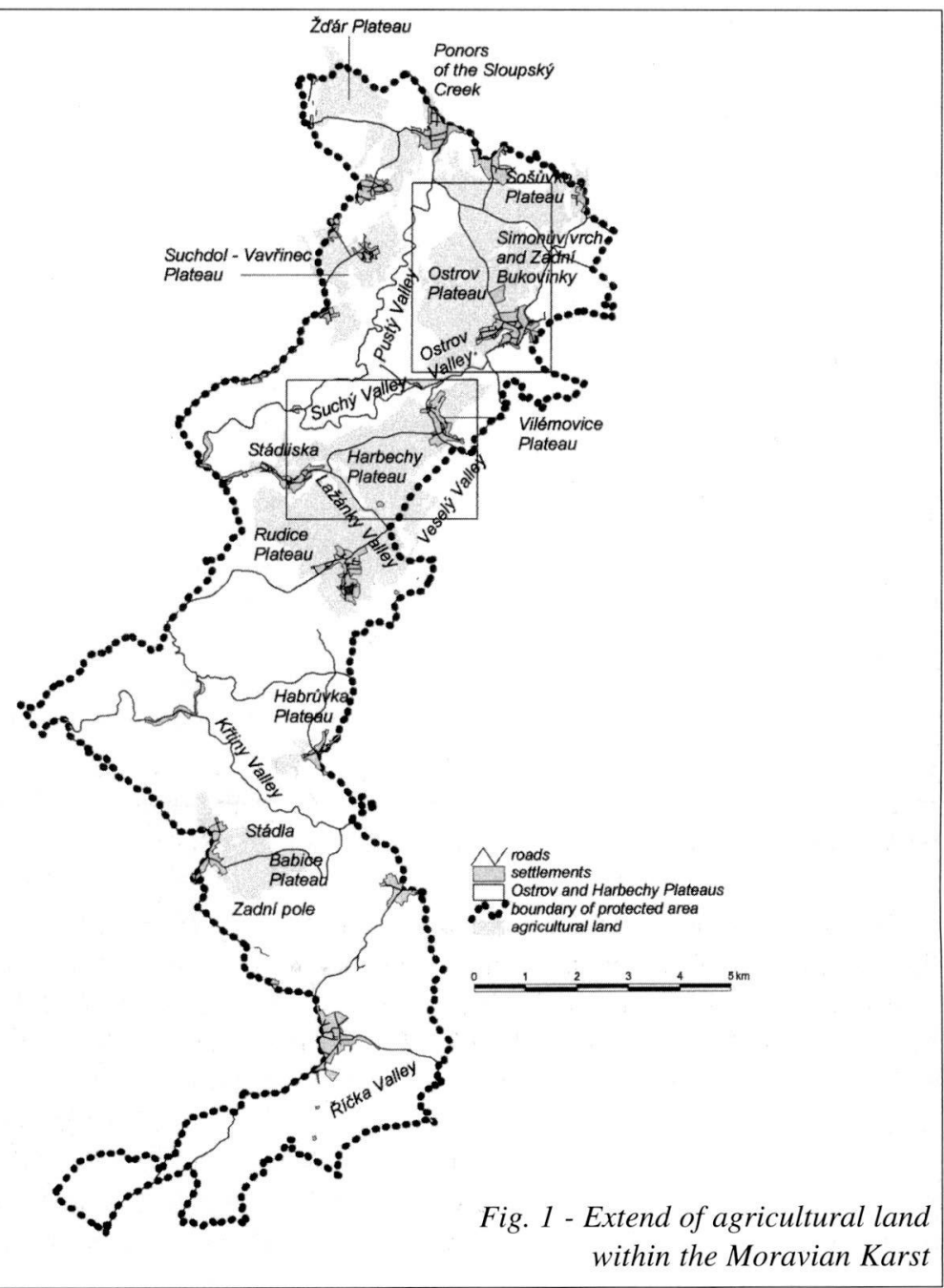


Brno Crystalline Massif (Proterozoic) composed mostly of granitoid rocks. Devonian sequences started by the sequence of siliciclastics, often varicoloured, sometimes with limestone intercalations. Basal clastics form the rim of the Moravian Karst on its whole western contacts with crystalline basement. The most important carbonate sequence of Middle/Upper Devonian age is the Macocha Formation consisting of Josefov, Lazánky and Vilémovice Limestones. The uppermost Devonian and Lower Carboniferous is represented by the Lísen Formation composed of nodular Køtiny Limestones in the north and Hády-Øíèka Limestones in the south. The total thickness of limestones exceeds $1.000 \mathrm{~m}$. Limestone sequences are overlain by Lower Carboniferous flysh sequences (shales, greywackes, conglomerates) of a great thickness. Paleozoic sequences are highly faulted and folded during the Variscan Orogeny (Dvoøák et al. 1993).

The platform cover is preserved only in denudation relics. Jurassic sandy limestones with cherts and spongilites occur near village of Olomuèany (Bosák 1978; Hanzlíková \& Bosák 1977). Deep Lower Cretaceous paleokarst forms filled with the Rudice Formation (sands, clays, iron ores) are well known especially from the Rudice Plateau (Bosák 1980, Bosák et al. 1979 a, b). Freshwater and marine Upper Cretaceous (Cenomanian to Turonian) sequences (sands, sandstones, marsitones) commonly overlie Jurassic and Lower Cretaceous sediments. The preservation of Mesozoic sequences is connected with the sunkened blocks of the Blansko Graben (Burkhardt 1974). Rests of marine Badenian sediments (clays, marls, sands, gravels, Miocene) fill some of deep karst valleys and smaller karst depressions (Burkhardt 1979; Dvoøák et al. 1993). Variety of sediments and residual sediments of the Quaternary age cover the surface with variable thickness (river terraces, loesses, soils, etc.; Dvoøák et al. 1993).

\section{Karst forms}

Favourable climatic and geological conditions supported the development of karst forms in several karst periods and phases (Kettner 1970; Bosák, Horáèek \& Panos 1989; Bosák 1997) which resulted in highly developed karst relief and subsurface karst drainage. Karst forms are developed especially within Devonian Lazánky and Vilémovice Limestones of the Macocha Formation.

Denudation surfaces (sensu Panos 1963), so-called plateaus, represent the typical form of georelief with altitudes of 400 to $550 \mathrm{~m}$ a.s.l. Plateaus are dissected by deep karst valleys (locally called glens) having NNE-SSW to NE-SW, NNW-SSE and approximately W-E axes. Valleys are commonly dry, flooded only during high precipitations. Only in some valleys, or in their lower courses stable streams are developed. Some plateaus show dense network of dolines (Ostrov and Harbechy Plateaus) and paleokarst forms (Rudice and Babice Plateaus). Some dolines were newly opened (diameter up to $10 \mathrm{~m}$, depth of 1 to $6 \mathrm{~m}$ ), especially on Ostrov, Sosùvka and Harbechy Plateaus as the consequence of wash down of artificial fillings in agriculturally utilised land.

About 1.000 caves have been known in the Moravian Karst. 200 of them are more 
important. The longest is the cave system of the Amatérská Cave in the northern part of the Moravian Karst with about $30 \mathrm{~km}$ of passages which are situated mostly under agricultural land.

The region is divided into three principal hydrological units with independent, especially subsurface hydrographic systems with unified base level. The Punkva River represents the main drainage of the northern part of the Moravian Karst. It is formed by subsurface confluence of the Sloupsky Creek and Bílá voda Creek in the Amatérská Cave. The larger part of the system of Amatérská Cave is lying below forests. The catchment area is $170 \mathrm{~km}^{2}$ and the average discharge is about $1 \mathrm{~m} / \mathrm{s}$. There is another, very poorly known, drainage system genetically related to so-called Maly vytok in the Pusty Valley. The system drains the Ostrov Plateau and represents the confluence of three allogenic streams, i.e. of Lopaè, Krasovsky and Vilémovicky Creeks.

The central part of the Moravian Karst is drained by the Køtinsky Creek and by the Jedovnicky Creek, which is its tributary. The catchment area is $70 \mathrm{~km}^{2}$ and the average discharge is $0,25 \mathrm{~m}^{3} / \mathrm{s}$. The Jedovnicky Creek created the second largest cave system of the region - Jedovnické propadání-Byèi skála Cave with the length of 13 $\mathrm{km}$. The creek appears in resurgences near the Byèi skála Cave as the Køtinsky Creek. One of important subsurface tributaries is the Tipeèek Creek supplying the Rudice village by potable water.

Another cave system was created by the Køtinsky Creek, nevertheless its dominant part in-between its ponors near village of Køtiny and its resurgence close to Byèi skála Cave has been still unknown. Hydrographic and hydrogeological conditions and connection are still waiting for detailed investigations. The drainage system lies below forests.

The southern part of the Moravian Karst is drained by several streams, i.e. the Ochozsky, Hostìnicky and Hádecky Creeks. The catchment area is $76 \mathrm{~km}^{2}$ and the average discharge is $0,16 \mathrm{~m}^{3} / \mathrm{s}$. The biggest cave of the region is Ochozská Cave representing level flooded by the Hostìnicky Creek. Subsurface streams form complex hydrographic net resurging as the Øièka Creek in two springs. Forests prevail above cave systems.

\section{Karst plateaus and agriculture}

On the territory of the Moravian Karst, the agricultural production is concentrated especially on karst plateaus. In a lesser extend, it is situated in the ponor areas of karst streams (e.g. Holstejnské and Sloupské Valleys) and at bottoms of karst valleys (Hradsky and Ostrovsky Glens). The agricultural land constitutes about 60 to $70 \%$ of the area of plateaus in the northern part of the Moravian Karst, while only 20 to $30 \%$ in the central and southern parts, where forests prevail (Fig. 1). Therefore, the clashes of interests of agriculture, karst systems and nature conservation is concentrated dominantly in the northern regions of the Moravian Karst. The list of plateaus below introduce briefly into the problem of karst forms and agriculture exclusively in the northern part of the Moravian Karst. Plateaus are listed according to orographic clas- 
sification of the Moravian Karst summarised by Bosák, Bílková \& Stárka (1994).

\section{Suchdol-Vavøinec Plateau}

The plateau is a part of the catchment area of the Sloupsky Creek. Several ponors of allogenic streams (i.e. of the Vavøinecky, Veselicky and Novodvorsky Creeks) are aligned along the contact of the Brno Massif and basal Devonian siliciclastics with limestones. Smaller steeply inclined caves are developed below sinks connecting sinks with the level of the subsurface Punkva River in the Amatérská Cave. Tracer experiment in the Suchdolsky Ponor in1992 proved the connection with Stajgrovka Cave in Pusty Glen. The group of shallow dolines on arable land near village of Nové Dvory is also drained into Stajgrovka Cave. The cave represents resurgence channel about 200 long aligned along the limestone/granitoid boundary. The inflow sump is utilised for local water supply of the most important tourist sites of the Moravian Karst. The arable land prevail on the surface of the plateau (about $70 \%$ of the area).

\section{Ostrov Plateau}

The plateau is the model area with important problems of agriculture and nature protection of the karst. It is extensive plateau intensively karstified limited by the Pusty Glen on the west and by the Suchy Glen on the east. Intensive agricultural production utilises about $80 \%$ of the plateau surface (Figs. 2 and 3). The plateau is subdivided into several smaller plateaus.

The northernmost part, known also as the Sosùvka Plateau, is developed at the boundary of limestones and flysh siliciclastics. Several lines of dolines are developed here. Some of dolines are opened to shaft-like caves with the depth of about 90 m (e.g. Sosùvská Chasm). Several small allogenic streams sink in these sinkholes feeding most probably some tributaries of the Punkva River in Amatérská Cave. The Holstejnská Cave of Nezamìstnanych is the largest below the plateau surface.

Fig. 2 - Ostrov

Plateau-the view to the central part with the dominance of arable land (photo J. Janèo, July 12 1998)

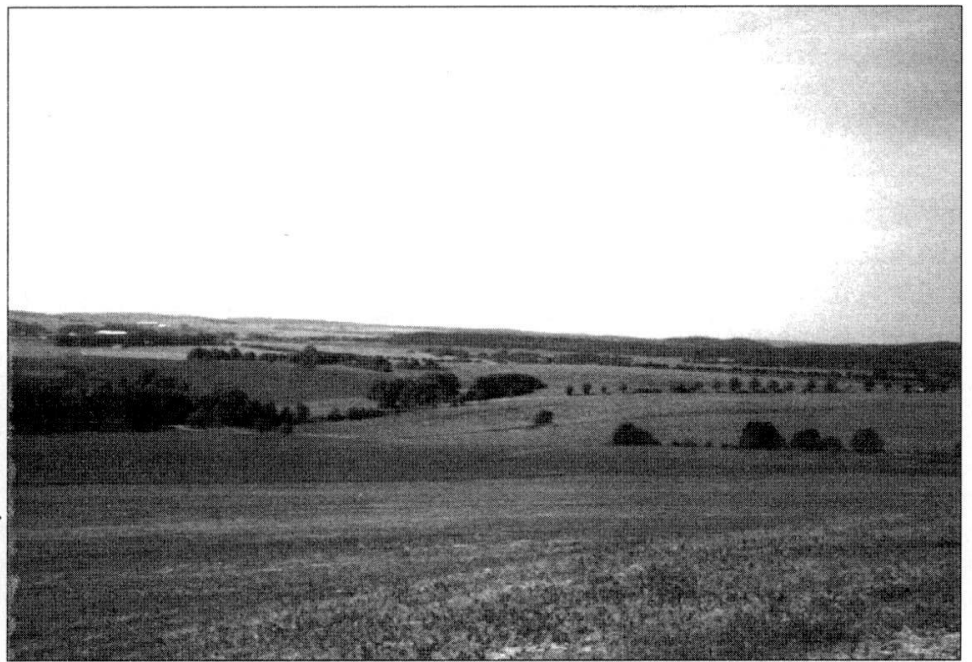




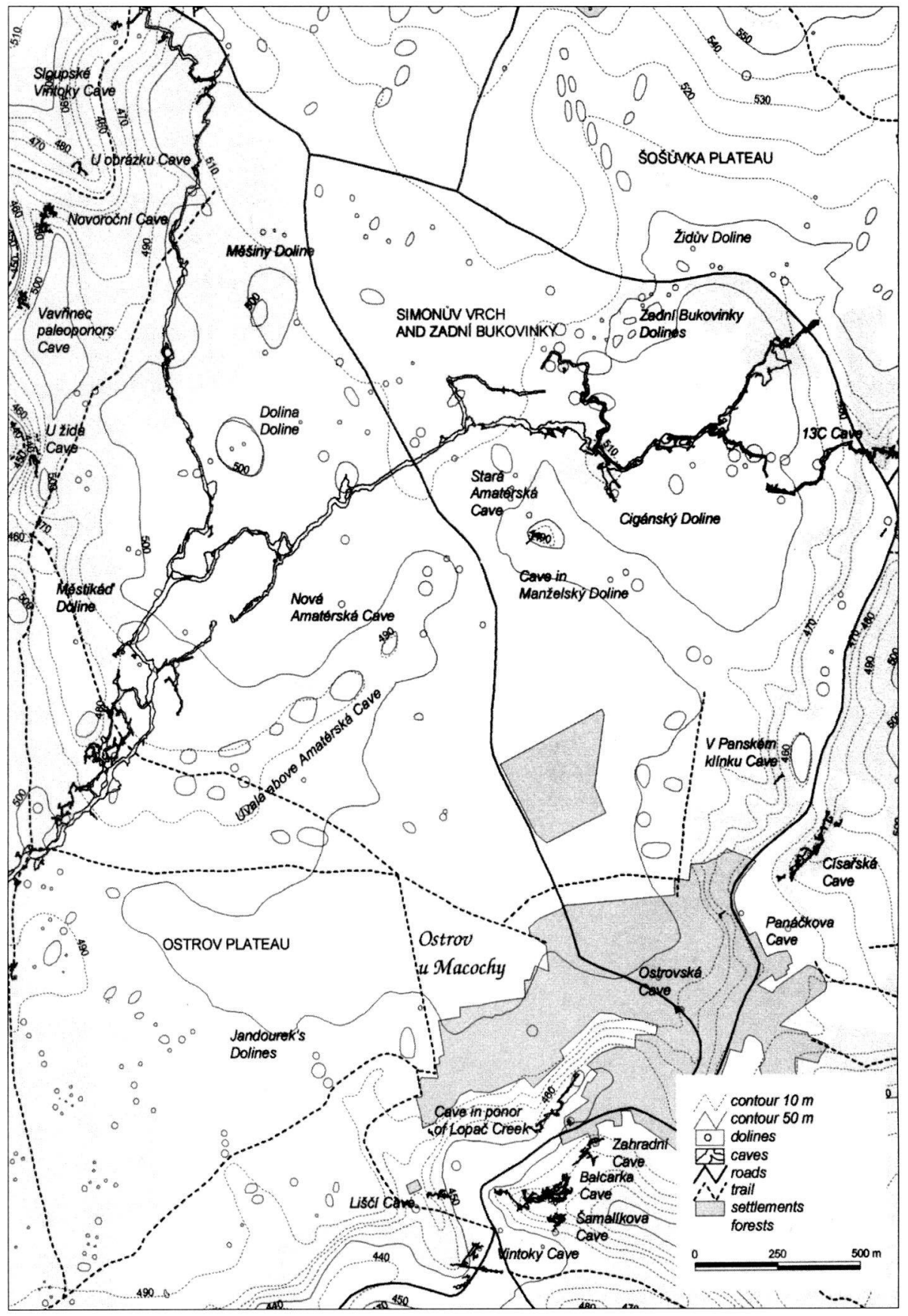

Fig. 3 - Ostrov Plateau (for location see Fig. 1) 
The Simonùv Hill and Zadní Bukovinky are the most intensively karstified part of the plateau. Zadní Bukovinky are the example of the relief with densely packed dolines. The most known cave here is Stará Amatérská Cave with active stream of Bílá voda Creek and several subsurface tributaries connected also with the region of Holstejnské Valley. In the depth of 70 to $120 \mathrm{~m}$ Amatérská Cave continues below the Ostrov Plateaus towards Macocha Chasm and the Punkva resurgence.

Amatérská Cave is the longest cave system in the Czech Republic with the length over $30 \mathrm{~km}$. Typical tunnel-shaped passages are periodically flooded by the Sloupsky, Bílá voda Creeks and Punkva River. Several smaller allogenic streams are connected with the cave system. Active subsurface stream of the Punkva River, except of several fragments, is generally unknown now.

Surface karst of the Ostrov Plateau is typical by numerous dolines, the largest ones (Dolina and Mìstikái) are directly connected with Amatérská Cave. Uvala above Amatérská Cave originated by amalgamation of line of dolines with the length of about $1.100 \mathrm{~m}$ and width of 200 to $400 \mathrm{~m}$. The uvala is parallel to Amatérská Cave by it lies about $250 \mathrm{~m}$ to the east.

Several smaller lines of dolines are developed in the southern part of the Ostrov Plateau. Dolines are probably connected with drainage of the Ostrovsky Glen.

\section{Harbechy-Vilémovice Plateau}

The region lies at the eastern border of the Moravian Karst. It is intensively utilised by agriculture, owing to its relatively thick cover of Quaternary sediments (loesses etc.). Typical groups of dolines are characteristic for the Vilémovice Plateau (Fig. 4). Some of dolines function as sinks of small streams (e.g. Vilémovicky Creek). The major part of ponors are explored up to the depth of 100 to $120 \mathrm{~m}$. There are drained towards the Maly vytok resurgence in Pusty Glen. Chasm-like caves with the length of about $1 \mathrm{~km}$ are developed here. Arable land prevails here (about $90 \%$ of agricultural land).

The Harbechy Plateau has somewhat different character, especially in the south. Extensive line of dolines with isolated groups of dolines is typical. Chasm-like caves (up to $-100 \mathrm{~m}$ ) lead to an active subsurface stream. Arable land dominate here $(95 \%$ agricultural land).

The Stádliska Plateau represents the highest part of the area above the Suchy Glen. Surficial karstification is only slight with shallow depressions. Meadows and pastures prevail here. The arable land represents only $30 \%$ of agricultural land.

\section{Rudice Plateau}

The plateau is forested, only the closest vicinities of villages of Rudice and Habrùvka serve as agricultural land (from it $65 \%$ is the arable land). The plateau is known by extensively preserved forms of Lower Cretaceous paleokarst. Sands and clays of the Rudice Formation were excavated for ceramic and foundry industry. Iron ores were mined here even in pre-historic times. Several more recent dolines are developed on the surface, as well as some fossil ponor valleys. 


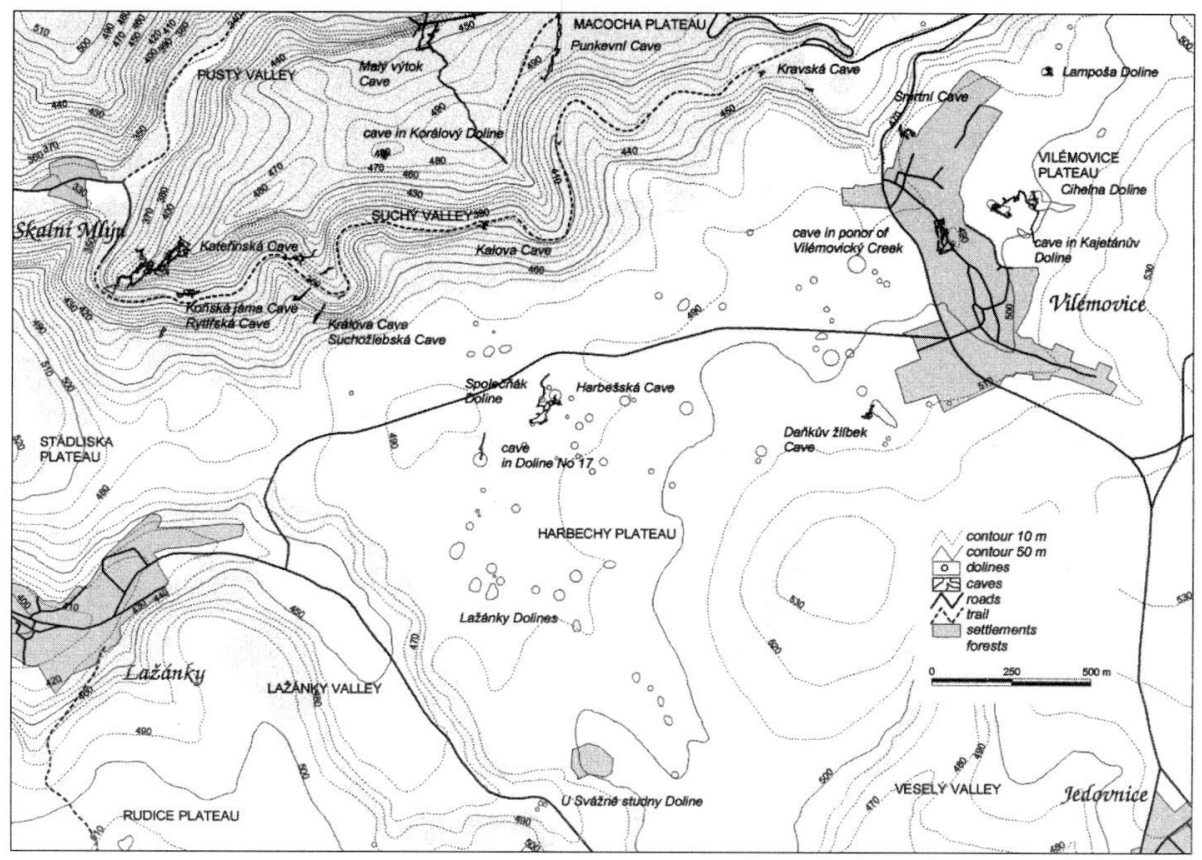

Fig. 4 - Harbechy-Vilémovice Plateau (for location see Fig. 1)

\section{Babice Plateau}

Stádla and Zadní pole Plateaus are agriculturally utilised parts of the Babice Plateau. The surficial karst relief is developed only scarcely on both plateaus. Shallow and extensive depressions prevail. The dominant part of group of dolines in Zadní pole Plateau were filled in the past. Subsurface drainage has not been known, except of rare exceptions. Borehole exploration and some speleological activities indicate intensive karstification with stabilised groundwater level at-100 m below the surface. Arable land represents $70 \%$ of agricultural land.

\section{Farming on karst plateaus}

\subsection{Agriculture and karst landscape}

Agricultural activity has taken part in the formation of the character of landscape of the Moravian Karst since the historic times. There were changes connected with the development of agriculture as a consequence of increasing number of inhabitants and the intensification of agricultural activities. Ecologically equilibrated landscape occurred here up to the half of $20^{\text {th }}$ Century. Levelled relief of karst plateaus with relatively thick cover of Quaternary sediments enabled the farming on fields. Slopes of valleys were suitable for farming on meadows and pastures. Therefore, arable land prevail on plateaus.

Character of settlement and type of housing in villages (around green or along 
road) determined also the arrangement of pieces of land within the cadaster. Plots formed either star-like arrangement from the centre of villages (e.g. Vavøinec, Vilémovice) or nearly closed circle around the village (e.g. Ostrov u Macochy). The estate of soil gradually disintegrated owing to increased number of inhabitants. Relatively less favourable natural conditions forced inhabitants to intensive utilisation and cultivation of each piece of land. Municipal forests on slopes of valleys were gradually cleared and changed to pastures. The whole upper part of the Suchy Glen was deforested which caused rapid soil erosion and limestone surface and karren were uncovered. According to photographs from the end of $19^{\text {th }}$ Century, the surface around village of Ostrov u Macochy and the major part of the Suchy Glen were deforested. Even deep dolines were then filled with material on fields of plateaus. Walls constructed from stones cleaned from fields preserved in some places up to the present time.

The intensification of agricultural exploitation started at the beginning of sixties of this century. It influenced unfavourably both surficial and subsurface karst forms (Fig. 5). Soil erosion was enhanced by amalgamation of fields and by the clearance of balks with scattered vegetation. The ploughing of fields up to the edges of dolines accelerates soil erosion. The eroded soil is transported through dolines and vertical

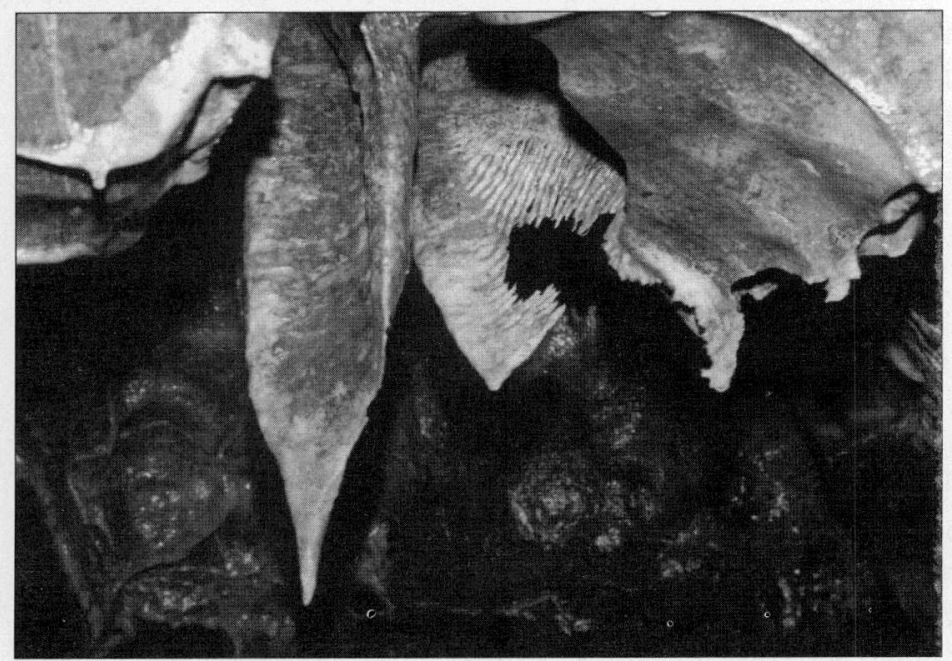

Fig. 5 - Corrosion of speleothems in the Amaterská Cave (photo L. Stefka, Sept. 20, 1997

cave systems into subsurface streams and through karst springs into surface streams. The extension of damages are illustrated by balance calculations of the content of dissolved and loaded matter in streams after the sudden storms. For example, on May 23, 1984 total precipitation of 35 to $45 \mathrm{~mm}$ was registered in the northern part of the Moravian Karst. During the maximum discharges $\left(12.1 \mathrm{~m}^{3} / \mathrm{s}\right.$, Tab. 1) with maximum rate of erosion, totally $51.3 \mathrm{t}$ of load and $1.47 \mathrm{t}$ of nitrates was transported by the Punkva River at Skalní mlyn site during 1 hour (Tab. 2).

The intensity of the utilisation of karst landscape is clearly visible in the structu- 


\begin{tabular}{|l|c|}
\hline Date & Discharge $\left(\mathbf{m}^{\mathbf{3}} / \mathbf{s}\right)$ \\
\hline May 23, 1984 & 1.36 \\
\hline May 24, 1984 & 12.12 \\
\hline May 25, 1984 & 8.43 \\
\hline May 26, 1984 & 4.93 \\
\hline
\end{tabular}

Table 1 - Discharges of the Punkva River at Skalni mlyn site after the sudden storm in the catchment area

\begin{tabular}{|l|c|c|c|}
\hline Date & Hour & Nitrates (mg/l) & Load (mg/l) \\
\hline May 24, 1984 & $09: 30$ & 300 & 1.050 \\
\hline May 24, 1984 & $15: 15$ & 31 & 550 \\
\hline
\end{tabular}

Table 2 - Contents of nitrates $\left(\mathrm{NO}_{3}{ }^{-}\right)$and load in the Punkva River at Skalni mlyn site during maximum discharge after the sudden storm in the catchment area.

re of plant production. The proportions of cereals and maize for ensilage increased and fodder crops decreased. This trend can be illustrated by the increase of sowed area of wheat from 559 ha in 1970 to 977 ha in 1979 and by the decrease of sowed fodder crops from 540 ha to 315 ha in the same time in the Agricultural Co-operative in village of Lipovec.

The increase in plants highly demanding the nutrients caused also the quantity of applied industrial fertilisers. Average doses of pure nutrients (nitrium-phosphatekalium $\{$ NPK $\}$ type) per 1 hectare of agricultural land exceeded $400 \mathrm{~kg} /$ year during the period of 1972 to 1980 in cadastres of villages of Ostrov u Macochy, Lazánky u Blanska, Holstejn, Veselice na Moravì and Sloup. The highest doses of 606 to $680 \mathrm{~kg}$ of NPK per 1 ha in 1972 and 1975 were applied on several tracts of land on the Ostrov Plateau (Stefka 1982; cf. also Fig. 6). The average doses for the whole Czech Republic was about 220 to $260 \mathrm{~kg}$ of pure nutrients (NPK) per 1 ha at this time.

Industrial fertilisers are leached from soils and they enter into cave systems. The influence of the style of farming to the quality of dripping water can be stated from the monitoring and comparison of quality of dripping water below agricultural land and below forests. The water quality was monitored by the former Institute of Geography of the Czechoslovak Academy of Sciences (up to 1980; Adámek and Rauser 1977; Adámek 1980), by the Authority of the Protected Landscape Area of the Moravian Karst (1981 to 1985; Stefka 1982; Kovaøík 1985) and by the Authority of Show Caves in the Moravian Karst (1991 to 1994; Zajíèek 1997). High content of dissolved matter in dripping waters in caves corresponded to high doses of industrial fertilisers on the surface. Nitrate content below agricultural land increased 10 times and chloride contents increased 3 times as compared with dripping waters below forests. The maximum nitrate concentration of $880.8 \mathrm{mg} / \mathrm{l}$ was reported from sampling in Amatérská Cave in 1979-1980 (Adámek 1983). This extreme value was not proved by repeated sampling in 1981-1996 carried out by the Authority of the 


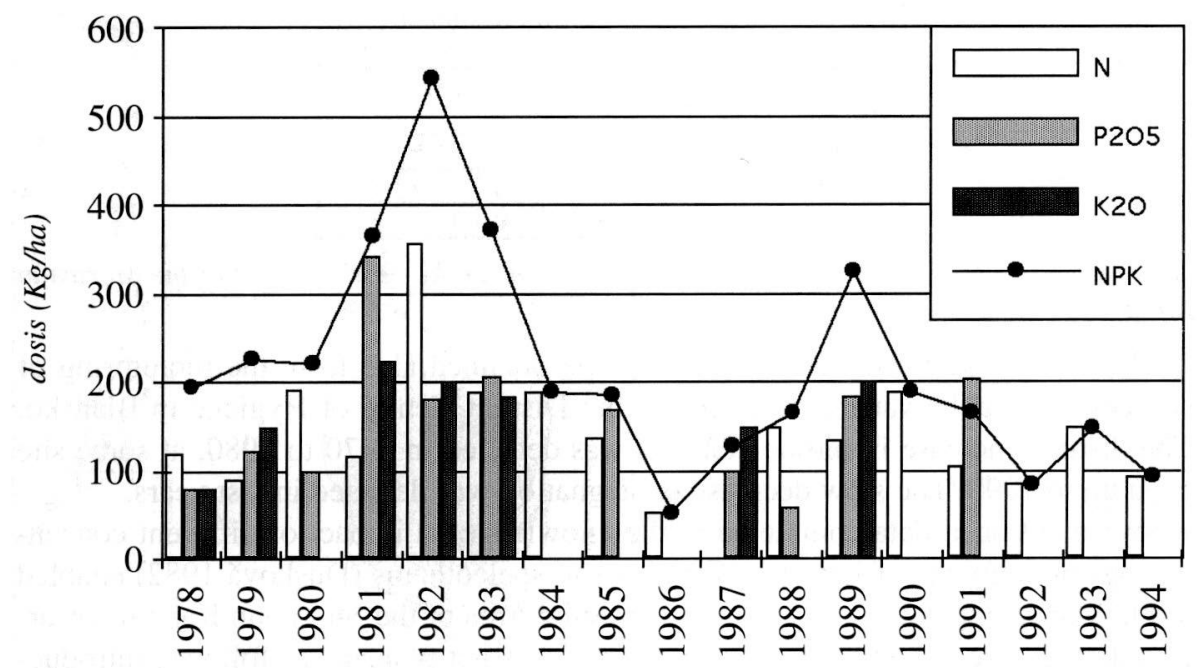

\begin{tabular}{|c|c|c|c|c|c|c|c|c|c|c|c|c|c|c|c|c|c|}
\hline & 1978 & 1979 & 1980 & 1981 & 1982 & 1983 & 1984 & 1985 & 1986 & 1987 & 1988 & 1989 & 1990 & 1991 & 1992 & 1993 & 1994 \\
\hline $\mathrm{N}$ & 120 & 91 & 192 & 118 & 357 & 189 & 190 & 137 & 54 & 0 & 150 & 135 & 190 & 106 & 84 & 148 & 94 \\
\hline P2O5 & 80 & 124 & 100 & 344 & 180 & 207 & 0 & 170 & 0 & 100 & 60 & 184 & 0 & 205 & 0 & 0 & 0 \\
\hline K2O & 80 & 149 & 0 & 225 & 200 & 185 & 0 & 0 & 0 & 150 & 0 & 200 & 0 & 0 & 0 & 0 & 0 \\
\hline NPK & 196 & 226 & 221 & 366 & 541 & 372 & 190 & 187 & 54 & 130 & 167 & 324 & 190 & 166 & 84 & 148 & 94 \\
\hline
\end{tabular}

Fig. 6 - Application of doses of industrial fertilisers in the Hranièák area.

Landscape Protected Area (unpubl.), when only 60 to $80 \mathrm{mg} / \mathrm{l}$ of nitrates were detected. Distinctly better water quality was detected below land covered by grass (nitrate content: average of $9 \mathrm{mg} / \mathrm{l}$ and maximum of $14 \mathrm{mg} / \mathrm{l}$ ). Unfortunately, analytical results from subsurface below places newly covered by grass are not available owing to the fact that were not successful to find responsible subsurface locations.

\begin{tabular}{|c|c|c|c|c|c|c|c|c|}
\hline \multirow{3}{*}{ Year } & \multicolumn{4}{|c|}{ Below arable land } & \multicolumn{4}{|c|}{ Below forest } \\
\hline & \multicolumn{2}{|c|}{$\mathrm{NO}_{3}^{-}(\mathrm{mg} / \mathrm{l})$} & \multicolumn{2}{|l|}{$\mathrm{Cl}^{-}(\mathrm{mg} / \mathrm{l})$} & \multicolumn{2}{|c|}{$\mathrm{NO}_{3}^{-}(\mathrm{mg} / \mathrm{l})$} & \multicolumn{2}{|l|}{$\mathrm{Cl}^{-}(\mathrm{mg} / \mathrm{l})$} \\
\hline & maximum & average & maximum & average & maximum & average & maximum & average \\
\hline 1981 & 115 & 65 & \multicolumn{2}{|c|}{ not detected } & 13 & 11.5 & \multicolumn{2}{|c|}{ not detected } \\
\hline 1982 & 107 & 79 & 64.1 & 50 & 13 & 8.9 & 21 & 15.5 \\
\hline 1988 & 82 & 22 & 69 & 48.5 & 46 & 2.8 & 41 & 8.9 \\
\hline 1989 & 78 & 58 & 69 & 48.2 & \multicolumn{2}{|c|}{ not detected } & \multicolumn{2}{|c|}{ not detected } \\
\hline 1995 & 136 & 76 & 50.1 & 29 & 13 & 6.4 & 6.7 & 4.5 \\
\hline 1996 & 136 & 87.7 & 51.5 & 32 & 5 & 4.2 & 9 & 4.8 \\
\hline
\end{tabular}

Table 3 - Quality of dripping water below arable land and forest (note: the variations of values depend on the type of plant production and treatment, specific permeability at site and hydrological situation). 


\begin{tabular}{|l|c|c|c|c|}
\hline \multirow{2}{*}{ Source-water supply } & \multicolumn{4}{|c|}{ Nitrates (mg/) } \\
\cline { 2 - 5 } & 1970 & 1980 & 1990 & 1996 \\
\hline $\begin{array}{l}\text { Skalní mlyn, } \\
\text { Stajgrovka Cave }\end{array}$ & 7.6 & 22.0 & 35.0 & 15.5 \\
\hline Kotinsky Creek & 11.0 & 28.0 & 21.5 & 13.5 \\
\hline Rudice village & 8.5 & 32.0 & 11.0 & 20.0 \\
\hline Züár-Nemcice village & 11.0 & 19.0 & 14.5 & 13.0 \\
\hline
\end{tabular}

Table 4 - Nitrate contents in sources of potable water in the northern part of the Moravian Karst (after District Centre of Hygiene Blansko).

The information on water quality can be obtained also from the monitoring of sources of potable water carried out by the District Centre of Hygiene in Blansko. The distinct increase in nitrate contents was detected in 1970 to 1980 , at some site even up to 1990. The slow decrease or stagnation was detected in last years.

Above mentioned data completed in the knowledge on impact of different concentrations of solutions of industrial fertilisers to speleothems (Dusková 1982) enabled to the Management of the Landscape Protected Area of the Moravian Karst to enforce some changes in agricultural exploitation of karst plateaus as follows: introduction of liquid industrial fertilisers, division of the total doses into several applications, extension of application of organic fertilisers, adjustment of sowing methods, changes in pesticide assortment, and introduction of grass to selected fields. About 20 ha of arable land was transformed to meadows (mostly above cave systems) and to infertile land (especially around dolines) during 1987 to 1989. Another 30 ha of arable land was changed to meadows in 1995 to 1997. The largest changes occurred on the Ostrov Plateau for the protection of the system of Amatérská Cave. In spite of mentioned changes, the arable land constitutes $80 \%$ of the area of agricultural land here (Fig. 7).

The dumping of wastes from production of animals represents special problem. Liquid waste is dumped in concrete pits. In the present time, the only open field dump of solid waste is situated near village of Ostrov u Macochy, and the construction of open field dumps are permitted only in the outer, 3rd zone of protection of the Moravian Karst. There is long-lasting discussion concerning the connection of increased $\mathrm{CO}_{2}$ contents in caves and the location of open field dump of solid waste from animal production. Otava (1990) and Havel (1991) reported $\mathrm{CO}_{2}$ concentration from 7.5 to $13.5 \%$ in caves in Harbechy and Babice Plateaus. Nevertheless, increased concentration were detected also in caves situated below forests.

\subsection{Protection of karst region and agriculture}

The protection of surficial and subsurface karst forms on plateaus and of their biocenoses is possible only when the intensity of agricultural production is decreased and followed by the change of arable land to meadows. The change represent the principal conflict of interests between agriculture and nature conservation in the present time. The problem of changes of field cultures due to nature conservation has not been yet finally solved because of financial questions and practical interests of agricultural subjects. 

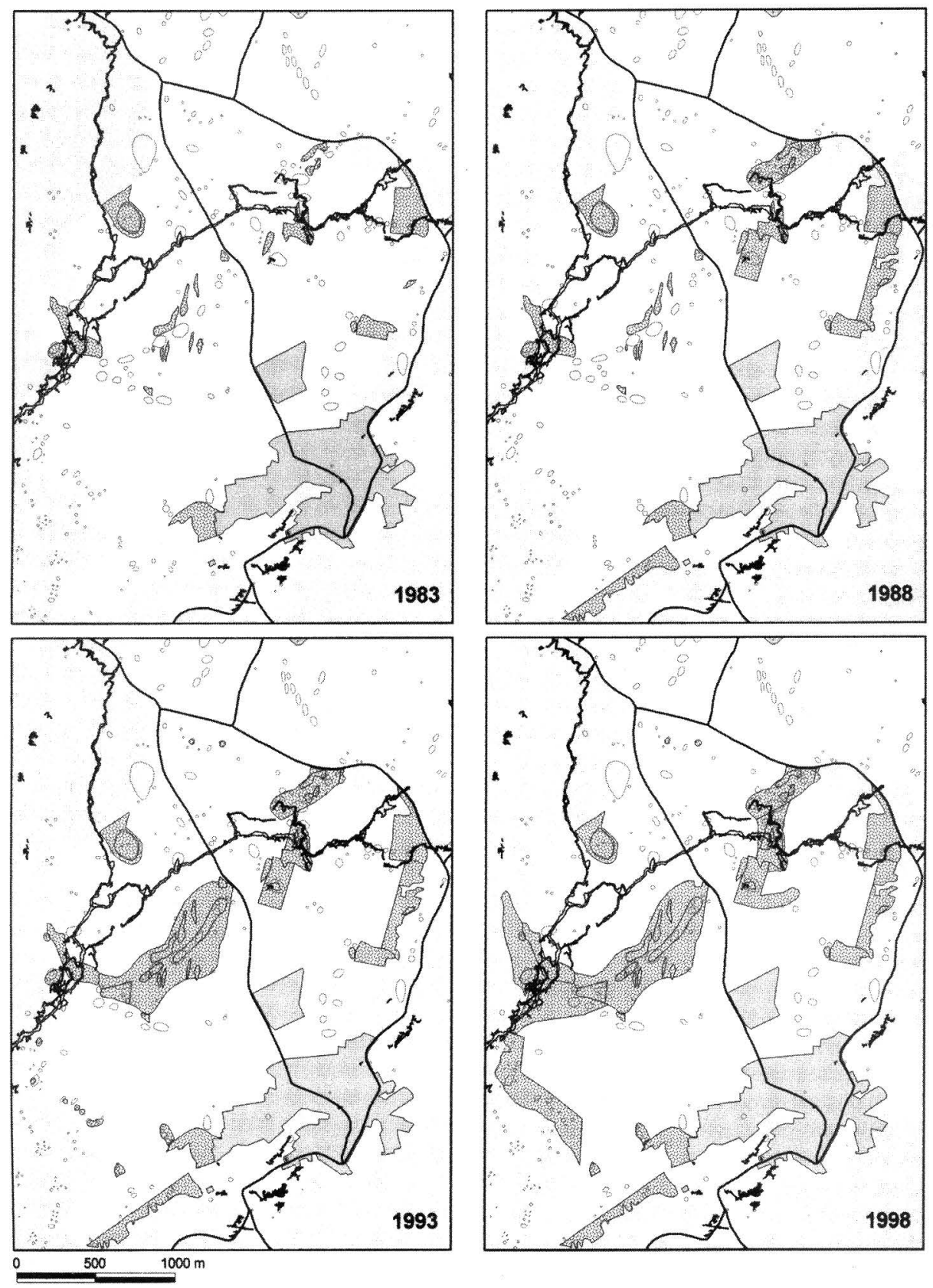

Fig. 7 - The succession of grass introduction on the Ostrov Plateau (dark grey - meadows; grey - settlements; light grey - forests; thick line - roads, ovals and circles - sinkholes; contour of caves are expressed by double or single line) 
The principal tool for nature conservation is the law on nature conservation from 1992. The protection of caves and other karst phenomena was introduced here for the first time. The law protects e.g. dolines from their filling by waste or other materials. The protection of the Moravian Karst was specified by the Ministry of Environment in 1994. The whole region was divided into three zones of protection. Zonation of agricultural land considered surficial and subsurface karst phenomena. The major part of arable land was included in the 3rd zone of protection, smaller part into the 2nd zone (about $200 \mathrm{ha}$ ) and the rest (about $120 \mathrm{ha}$ ) into the most strictly protected 1st zone (cf. Fig. 8).

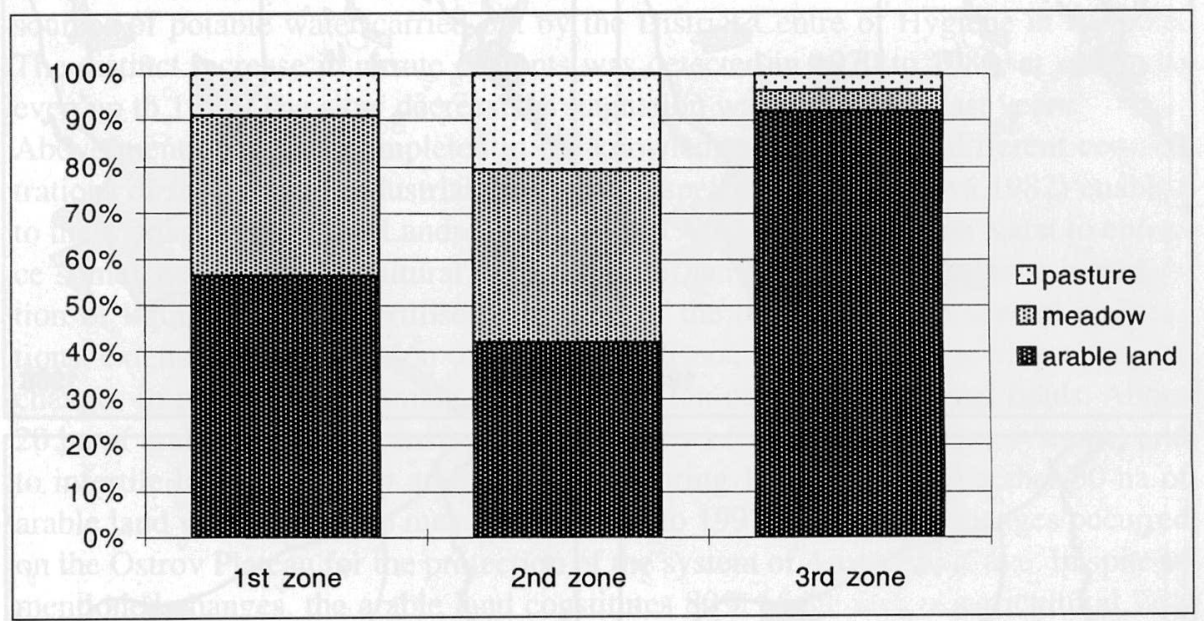

\begin{tabular}{|l|c|c|c|}
\hline & 1st zone & 2nd zone & 3rd zone \\
\hline arable land & 162 & 199,9 & 2625,4 \\
\hline meadow & 98,9 & 177 & 126,8 \\
\hline pasture & 26 & 97,4 & 99,4 \\
\hline
\end{tabular}

Fig. 8 Proportions of agricultural cultures in individual zones of protection in the cadaster of the Landscape Protected Area of the Moravian Karst.

According to law on nature conservations, in the 1st zone o protection, there is forbidden to apply fertilisers and liquid waste from animal and plant production. The zone includes agricultural land in small-scale especially protected areas (reserves) and lands (partly also arable land) with high concentration of surficial and underground karst forms (e.g. on Ostrov and Harbechy-Vilémovice Plateaus; cf. Figs. 9 and 10). There is the plan to introduce here the intensive farming on meadows and pastures with production of cattle, sheep and goats without application of pesticides and fertilisers. Arable land will be gradually transformed to meadows and pastures by introduction of grass cover.

In the 2 nd zone of protection, there is not allowed to farm on land outside buildup areas using intensive technologies, application of biocides, to change water regi- 
me and to make extensive changes of the terrain. The zone includes agricultural land with scattered occurrence of surficial and subsurface karst forms and protection zones of important karst phenomena classified into the 1st zone. There is expected intensi-

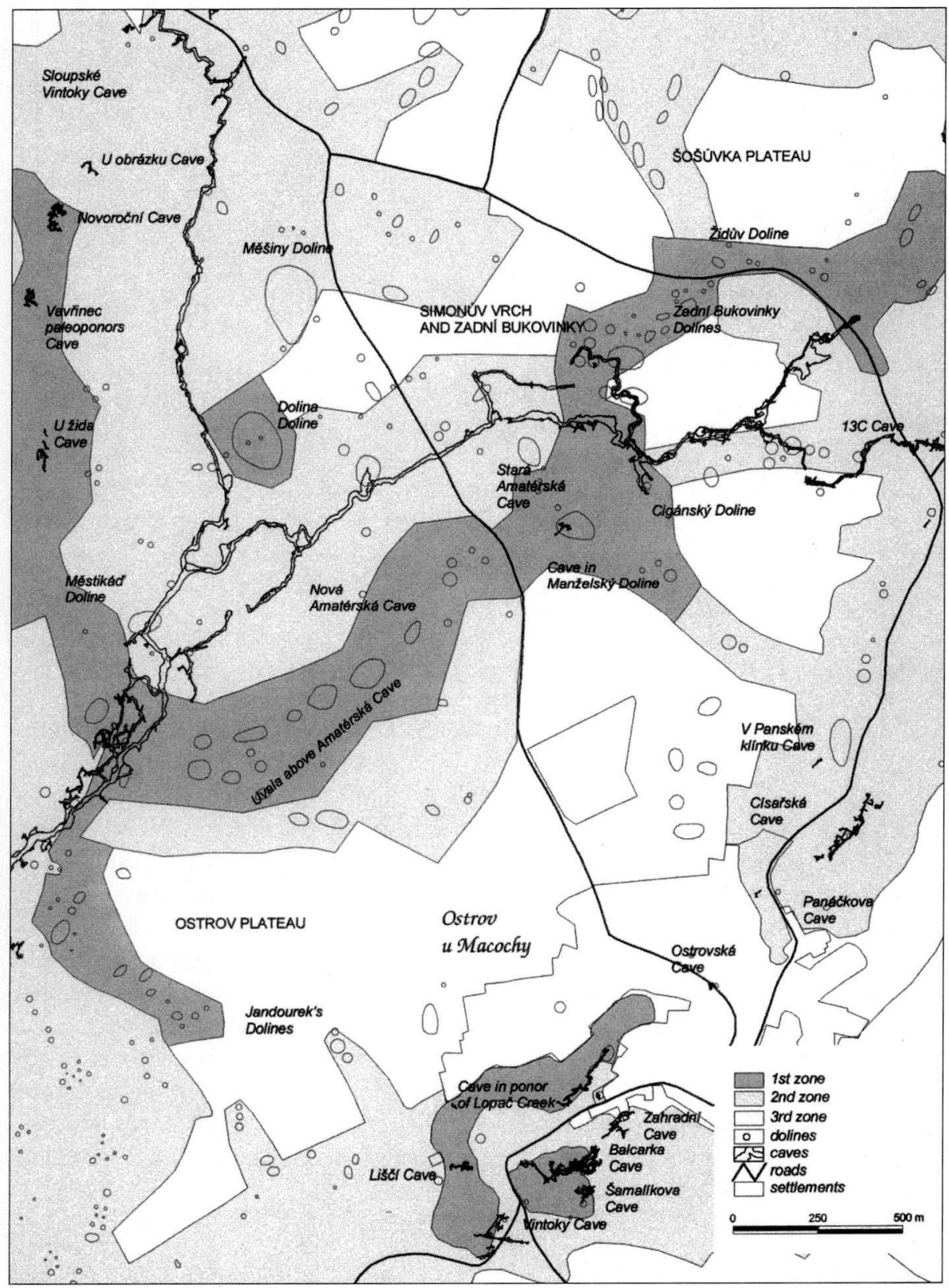

Fig. 9 - Zones of nature protection of the Ostrov Plateau (for explanations of symbols see Fig. 2). 


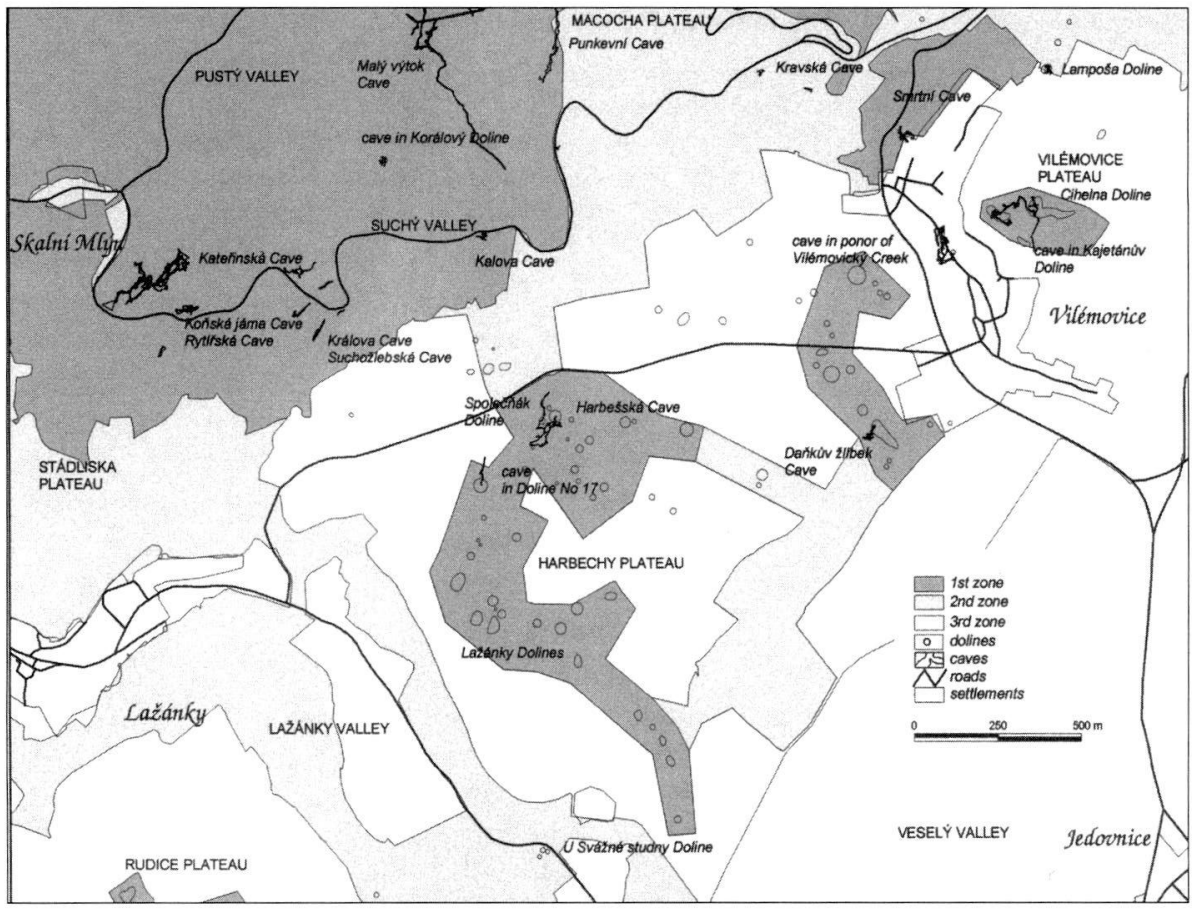

Fig. 10 - Zones of nature protection of the Harbechy-Vilémovice Plateau (for explanations of symbols see Fig. 2).

ve farming on meadows and pastures, eventually farming on arable land with decreased application of pesticides and fertilisers and preferred use of organic fertilises. Selected areas of arable land will be gradually changed to meadows and pastures.

Land intensively exploited were classified into the 3rd zone of protection (i.e. arable land, gardens) with rare occurrence of karst forms. The reasonable support of agriculture in the optimal form, including development of ecological agriculture, is the aim here. Air application of pesticides and fertilisers should be excluded.

The regimes of farming in individual zones of protection and proposals of practical changes in agricultural cultures and conservation and stabilisation of karst phenomena are stated in the Plan of care on the Landscape Protected Area approved in 1997. The Government of the Czech Republic approved the territorial plan of the protected area of the Moravian Karst in 1998 stating, e.g.: "the farming had to be subordinated to conditions of nature and landscape conservation and water management. The introduction of grass have to be finished on arable land within the 1st zone of the Landscape Protected Area above cave systems".

\section{Proposals of future management}

The adjustment of farming on the territory of the Moravian Karst represents one 
of the most important factors influencing future protection of the area. However, assumed changes are connected with the economic development of the region. Prazan, Drlík \& Novotná (1998) evaluated economical impacts of adjustment of farming from the point of view of nature conservation. After the consultations with farmers, following variant seems to be optimal, i.e. to finish the introduction of grass on arable land within the 1 st zone of protection (162 ha), and to introduce specific sowing methods in the 2 nd zone of protection ( $277 \mathrm{ha}$ ). The cost of grass introduction in the 1st zone will total 1.7 mio CZK during the first year, and about 1.1 mio $\mathrm{CZK}$ in following years annually (exchange rate approx. $35 \mathrm{CZK}=1 \mathrm{USD}$ ). The impact of changes of sowing methods is individual according to individual pieces of land. If the land in the 2nd zone is not extensive, the costs are considerably low. Where areas of land are extensive, e.g. on Ostrov Plateau, the cost of the introduction of alternative sowing method is high owing to decrease in areas with wheat production. Another problem is representing by small farmers with low area of owned land. Here, the introduction of grass and new sowing methods would completely change the style of farming bringing no profit from the production.

The system of long-lasting financing of the project of adjustment of farming resulting from nature conservation has been still unsolved. The budget regulation do not allow to sign contracts for period of several years with the full guarantee of refund after the first year finished. The finances are approved each year repeatedly. To be closer to a common practice in the European Union, it would be necessary to sign the eco-agricultural programs at least for five years and to deepen the co-operation of agriculture with nature conservation to enable to introduce program of careful farming within specifically protected areas.

\section{REFERENCES}

ADÁMEK Z. 1980. Pollution of streams and catchment areas in the northern part of the Moravian Karst by villages (in Czech). In: Proc. Symp. Water-environment-problems of water in mountainous areas. High Tatras.

ADÁMEK Z. 1983. Influence of agricultural production in he Moravian Karst to the evolution of water quality in the catchment area of the Punkva River (in Czech). Sborník prací pedagogické fakulty University J.E. Purkynì v Brnì, 81, øada pøírodních vìd, 13: 79-92. Brno.

ADÁMEK Z. \& RAUSER J. 1977. Contribution to the problem of karst water pollution. Studia Geographica, 62: 93-101. Brno.

BOSÁK P. 1978. Rudice Plateau in the Moravian Karst-part III. Petrography and diagenesis of carbonates and silicites of the Jurassic relic at Olomuèany (in Czech., Engl. summ.). Acta Musei Moraviae, Sci. nat., 63: 7-28. Brno.

BOSÁK P. 1980. Lower Cretaceous fossil karst of the Rudice Plateau in the Moravian Karst (in Czech, Engl. summ.). Èeskoslovensky kras, 31 (1979): 57-67. Praha.

BOSÁK P. 1997. Paleokarst of the Bohemian Massif in the Czech Republic: an overwiev and synthesis. Int. J. Speleol., 24 (1995), 1-2: 3-40.

BOSÁK P., BÍLKOVÁ D. \& STÁRKA L. 1994. Karstological division of the Czech Republic (in Czech). MS, Czech Speleol. Soc. and Czech Inst. Nature Conserv.: 1-81. Praha.

BOSÁK P., GLAZEK J., GRADZIÑSKI R., WÓJCIK Z. 1979a. Genesis and age of sediments of the Rudice type in fossil-karst depressions. Ėasopis pro mineralogii a geologii, 24, 
2: 147-154. Praha.

BOSÁK P., GLAZEK J., GRADZIÑSKI., WÓJCIK Z. 1979b. Problems of genesis and age of deposits of the Rudice type filling fossil karst forms (in Polish, Engl., French summ.). Kras i Speleologia, 2(11, 1978): 11-15. Katowice.

BOSÁK P., HORÁÈEK I. \& PANOS V. 1989. Paleokarst of Czechoslovakia: 107-135. In: BOSÁK P., FORD D.C., GLAZEK J. \& HORÁĖEK I. (Eds.) - Paleokarst. A Systematic and Regional Review. Elsevier-Academia, Amsterdam-Praha.

BURKHARDT R. 1974. Rudice Plateau in the Moravian Karst-part I. The contribution to the theory of fossil karst and geological evolution (in Czech, Germ. summ.). Acta Musei Moraviae, Sci. nat., 59: 37-58. Brno.

BURKHARDT R. 1979. Remarks on genesis of fossil karst near village of Rudice (Moravia)(in Polish, Engl., French summ.). Kras i Speleologia, 2 (11, 1978): 23-26. Katowice.

DUSKOVÁ M. 1982. The study of influence of unfavorable factors of environment to karst form of the Moravian Karst (in Czech). MS, Dipl. Thesis: 40 pp. Pardubice Univ. Pardubice.

DVORÁK J., STELCL O., DEMEK J. \& MUSIL R. 1993. Geology and geomorphology of the Moravian karst: 31-76. In: MUSIL R. (Ed.) - Moravian Karst-the labyrinth of knowledge, GeoProgram Adamov.

HANZLÍKOVÁ E. \& BOSÁK P. 1977. Microfossils and micro facies of the Jurassic relict near Olomuèany (Blansko district). Vìstník Ústøedního Ústavu geologického, 52: 73-79. Praha.

HAVEL H. 1991. Cave and carbon dioxide (in Czech, Engl. abs.). Speleofórum 91: 71. Brno.

KETTNER R. 1960. Morphological evolution of the Moravian Karst and its surroundings (in Czech, Engl. summ.). Èeskoslovensky kras, 12: 47-84. Praha.

KOVAØÍK M. 1985. Protection of water quality in the Landscape Protected Area of the Moravian Karst (in Czech): 233-236. In: Proc. VII. Conf. Czechoslovak Limnological Society. Nitra.

OTAVA J. 1990. Carbon dioxide in caves (in Czech, Engl. abs.) Speleofórum 90: 64-65. Brno.

PANOS V. 1963. On the origin and age of denudation surfaces in the Moravian Karst (in Czech. Engl. summ.). Èeskoslovensky kras, 14 (1962-1963): 29-41. Praha.

PRAZAN J., DRLÍK J. \& NOVOTNÁ Z. 1998. Evaluation of economic impacts caused by changes in farming of agricultural subjects within the Landscape Protected Area of the Moravian Karst as a consequence of nature conservation and protection of karst forms. MS, Res. Inst. Agricult. Econ. Praha-Brno.

STEFKA L. 1982. Agricultural production in the Landscape Protected Area from the point of view of nature conservation (in Czech): 66-70. In: 10th Conference on Biosphere. Quality Standards on Environment. Praha.

ZAJíĖEK P. 1997. Hydrochemical investigation of surficial and dripping waters in the northern part of the Moravian Karst (in Czech, Engl. summ.). Ochrana Pøírody, 6: 167-169. Praha. 